\title{
Galong dan Pathet Manyura dalam Pedalangan Ngayogyakarta: Sebuah Perbandingan "Rasa"
}

\author{
Aris Wahyudi dan Rani Kurniawati ${ }^{1}$ \\ ${ }^{1}$ Program Studi S-1 Pedalangan, Fakultas Seni Pertunjukan, Institut Seni Indonesia Yogyakarta
}

\begin{abstract}
Galong and Pathet Manyura in Ngayogyakarta Puppetry: A Comparison of "Rasa". Galong is a unique and exciting phenomenon in the world of puppetry. Its capacity as a "pathet" is still in debate today. Some groups say that Galong is the "pathet" itself, while others say Galong is part of the "Manyura pathet". The controversy arises because its presence in the puppet show is in "Manyura's pathet", but it has a distinctive in which it uses the fifth tone prominently. As a result, Galong has a different musical feel to "Manyura's pathet". On the other hand, the fifth tone is the dominant tone in sanga pathet and becomes abstinence in "Pathet Manyura". This research used comparative method to compare "rasa" (the feel) of gendhing-gendhing Galong in pedalangan and karawitan to "pathet" "Nem", "Sanga", and "Manyura". The focus of Galong being reviewed concerning puppet shows is the following: (1) How is the Playon Galong "rasa"?; (2) What is the function of galong in ngayogyakarta pakeliran tradition? The analysis using the perspective of martapangrawit's "padhang-ulihan" and functionalism concluded that Galong belonged to the "Manyura pathet". The fifth tone, as the thin tone is presented as "pancer" or "padhang" to reinforce "ulihan" tones. Thus, the feel is more sereng than the feel produced by "Playon Manyura", which has a strong "padhang-ulihan" tone. In other words, Galong has its function as a transition to the climax or "manyura sampak" in a puppet show.
\end{abstract}

Keywords: galong; comparison; puppetry; rasa; functions

\begin{abstract}
ABSTRAK
Galong adalah fenomena unik dan menarik di dunia pedalangan. Kapasitasnya sebagai pathet masih menjadi perdebatan sampai sekarang. Sebagian kelompok mengatakan bahwa Galong merupakan pathet tersendiri, sedangkan golongan lain menyatakan Galong adalah bagian dari pathet Manyura. Perdebatan itu muncul karena kehadirnnya dalam pertunjukan wayang berada di dalam pathet Manyura, namun dia memiliki ciri khas, yakni digunakan nada lima yang relatif menonjol sehingga Galong memiliki nuansa musikal yang berbeda dengan pathet Manyura. Pada sisi lain, nada lima merupakan nada dominan dalam pathet Sanga dan menjadi pantangan dalam Pathet Manyura. Penelitian ini menggunakan metode komparatif untuk memperbandingkan rasa musikal gendhing-gendhing galong dalam pedalangan dan karawitan dengan pathet Nem, Sanga, dan Manyura. Yang menjadi fokus permasalahan galong dalam kaitannya dengan pertunjukan wayang adalah: (1) Bagaimana "rasa" Playon Galong?; (2) Apa fungsi galong dalam tradisi pakeliran Ngayogyakarta? Analisis menggunakan perspektif "padhang-ulihan" Martapangrawit dan fungsionalisme diperoleh kesimpulan bahwa Galong termasuk pathet Manyura. Nada lima sebagai nada tipis dihadirkan sebagai "pancer" atau nada padhang untuk memberi penguatan pada nada dhong atau ulihan. Dengan demikian diharilkan rasa yang lebih sereng dibanding rasa yang dihasilkan playon Manyura yang memiliki nada padhang-ulihan sama kuatnya. Atau dengan kata lain, bahwa fungsi Galong adalah sebagai transisi menuju klimaks atau sampak Manyura dalam pertunjukan wayang.
\end{abstract}

Kata kunci: galong; komparasi; pedalangan; rasa; fungsi

Alamat korespondensi: Program Studi S-1 Pedalangan, Fakultas Seni Pertunjukan, Institut Seni Indonesia Yogyakarta, Jalan Parangtritis Km. 6.5 Yogyakarta. E-mail: ariswahyudi@gmail.com; HP.: 081215607669. 


\section{Pendahuluan}

Galong merupakan fenonema yang unik dan menarik. Dikatakan unik karena Galong adalah salah satu bentuk karawitan dalam pertunjukan wayang (selanjutnya ditulis pakeliran) hanya dijumpai dalam pakeliran tradisi Ngayogyakarta. Dikatakan menarik karena: pertama, penempatan Galong dalam pakeliran berada di tengah-tengah pathet Manyura. Kedua, khususnya playon Galong terdapat hal yang tidak lazim sebagai pathet Manyura karena menngunakan nada lima sebagai pancer. $\mathrm{Hal}$ itulah tampaknya yang menjadikan perdebatan di kalangan seniman karawitan mengenai kapasitas Galong. Sebagian kelompok mengatakan bahwa Galong merupakan pathet tersendiri, sedangkan sebagian yang lain mengatakan bahwa Galong adalah pathet Manyura.

Golongan yang menyatakan bahwa Galong merupakan pathet tersendiri didasarkan pada kenyataan fenomena Galong itu sendiri. Galong tidak hanya playon saja, tetapi juga terdapat gending yang lain, baik berbentuk gendhing, ketawang, ladrang, maupun lancaran. Galong dalam pedalangan tradisi Ngayogyakarta juga terdapat dalam bentuk sulukan, baik ada-ada maupun suluk. Ketika dalang membawakan sulukan Galong, adalah penanda kepada pengrawit bahwa selanjutnya harus membawakan gending yang bernuansa Galong. Fenomena demikian menjadikan Galong dipandang memiliki kelengkapan sebagai pathet tersendiri karena ada sulukan beserta gending-gendingnya. Seperti halnya pathet yang lain, sulukan juga sebagai salah satu penanda perpindahan pathet.

Dasar yang digunakan untuk menyatakan bahwa Galong merupakan pathet Manyura adalah konvensi pathet dalam karawitan pada umumnya. Sebagaimana dipahami dalam dunia karawitan pada umumnya, baik tradisi Surakarta, Jawa Timuran, dan Banyumasan bahwa pathet hanya terdiri dari tiga, yaitu pathet Nem, Sanga, dan Manyura untuk tradisi Surakarta dan Banyumasan; untuk tradisi Jawa Timuran adalah pathet Wolu, Sepuluh, dan pathet Serang. Galong hanya terdapat dalam tradisi pedalangan Ngayogyakarta.

Galong, meskipun menggunakan nuansa nada lima, tetapi selehing gending menggunakan nada dhadha (3) atau barang (1), yakni nada dominan untuk pathet Manyura. Pathet dalam dunia karawitan, selain sebagai pembangun karakter dan watak gending, juga dipahami sebagai simbol siklus kehidupan manusia (Sudarko, 2003). Rasa gending yang dibangun oleh pathet dibutuhkan untuk mendukung peristiwa dalam pakeliran. Berdasarkan fenomena tersebut di atas, maka yang menjadi pertanyaan adalah: (1) Bagaimana "rasa" playon Galong?; (2) Apa fungsi playon Galong dalam pakeliran?

Istilah galong, pada dasarnya lebih popular dalam dunia pedalangan. Hal demikian tentu sangat erat dengan fungsi dan peranannya dalam pakeliran, terutama dalam hal pembabakan maupun pengadegan, dan berperan penting dalam memperkuat atau mempertegas unsur dramatic (Nugroho, 2019). Satu hal yang lebih penting bahwa persoalan pathet tidak dapat dilepaskan dari struktur pakeliran yang sirkuler (Wikandaru \& Sayuti, 2019).

\section{Metode Penelitian}

Penelitian ini merupakan penelitian kualitatif, dengan objek kajian difokuskan pada data yang terdapat dalam buku Pedhalangan Ngayogyakarta karya Mudjanattistomo dkk. Data yang diperoleh dari rekaman $\mathrm{mp} 3$, youtube, menyaksikan pertunjukan wayang secara langsung, serta wawancara, bukanlah untuk sampel guna mendapatkan generalisasi pemikiran, melainkan sebagai referensi dalam analisis, baik sebagai pembenar maupun tidak. Narasumber dalam penelitian ini tidak dilakukan levelisasi berdasarkan usia seperti yang dilakukan Beate Muschalla dan Margó Weimann (bandingkan dengan Muschalla \& Weimann, 2021).

Langkah selanjutnya memperbandingkan rasa musikal yang dihasilkan oleh komposisi laras dalam gendhing Galong dengan gendhing dalam pathet Nem, Sanga, dan Manyura, menurut pandangan Hastanto (2009) dan Soeroso (1985). Hal penting yang harus diperhatikan dalam studi perbandingan adalah: peneliti harus netral dan menghilangkan rasa kepberpihakan terhadap salah satu 'pihak' yang diperbandingkan, serta pengaruh pemikiran lain yang merugikan penelitian (Simon, 2020). 


\section{Hasil dan Pembahasan}

Masyarakat Karawitan memahami bahwa unsur gending meliputi balungan yang merupakan struktur gending dan irama atau laya (bandingkan dengan Hastuti \& Mustafa, 2016). Rasa gending adalah karakter musikal yaitu nuansa tertentu yang ditimbulkan oleh alunan gending (Setiawan, 2019). Berkenaan dengan hal ini, Hastanto menyatakan bahwa pathet sebenarnya adalah permasalahan yang berkaitan dengan rasa gending, yaitu rasa seleh atau rasa berhenti pada sebuah kalimat lagu, atau tanda baca titik dalam fenomena bahasa (Hastanto, 2009). Rasa gending dalam dunia karawitan sangat ditentukan oleh komposisi padhang-ulihan, dari level terkecil (satu kethuk), level kenong, sampai level terbesar (satu gongan). Satu kalimat lagu dalam ladrang, ketawang, dan gendhing, adalah satu kenongan. Kalimat lagu dibagi menjadi level yang lebih kecil, yaitu gatra, dan paling kecil adalah kethuk. Padhang-ulihan selalu terbangun, baik dalam satu kenong, gatra, maupun kethuk. Artinya bahwa padhang-ulihan ini pun juga bertingkat, dari kethuk sampai gong (Ayu Fitria, 2018). Dengan demikian telaah padhang-ulihan ini dimulai dari level kethuk yang terdiri dari dua nada. Artinya bahwa satuan terkecil dalam gending adalah relasi dua nada yang disebut padhang-ulihan (Soeroso, dkk. 1985). Dalam konsep pembentukan pathet, dhing memiliki "tekanan" ringan dan dhong bertekanan berat. Sebagai unsur terkecil, padhangulihan belum memiliki arti tetapi memiliki entitas. Dia akan memiliki makna apabila direlasikan dengan padhang-ulihan yang lain dalam sebuah bentuk gending, yakni 16 balungan untuk bentuk ketawang dan lancaran, 32 balungan untuk ladrang dan ketawang gendhing, 32 untuk gendhing dan seterusnya (Martopangrawit, 1975) dan (Suhastjarja, dkk. 1985).

Widodo dan kawan-kawan mengutip pandang an Rahayu Supanggah bahwa kualitas komposisi karawitan sangat ditentukan oleh kesesuaiannya dengan prinsip estetika dan budayanya sehingga menghasilkan rasa komposisi karawitan yang menekankan karakter gending (Widodo, Susetyo, Walton, \& Appleton, 2021). Analisis rasa pathet dalam penelitian ini didasarkan pada ricikan gen- der. Hal demikian didasarkan pada pemahaman bahwa gender dipandang sebagai struktur dasar dalam gamelan (Sergeant \& Himonides, 2016). Berkenaan dengan rasa pathet, Hastanto (2009) menyebutkan bahwa untuk mengidentifikasi pathet atas sebuah gendhing dapat ditelaah nada selehnya berdasarkan patokan pada Tabel 1 .

Soeroso (1985) menjelaskan visualisasi bahwa pathet sebuah gending terdapat kunci-kunci nada tertentu yang berfungsi sebagai pembentuk pathet. Nada-nada tersebut adalah dhong, dheng, dhung, dhang dan dhing atau sering disingkat O, E, U, A dan I. Nada dhong adalah akhirnya lagu atau seleh. Dheng adalah pelengkap yang menjadi lintasan nada dalam lagu. Nada dhung adalah kempyung bawah yang sering berfungsi sebagai seleh. Nada dhang adalah kempyung atas yang juga berfungsi nada seleh. Nada dhing bertekanan ringan yang menjadi pantangan dalam pathet. Pengertian kempyung di sini bukan berarti dua nada harmoni yang ditabuh bersamaan, tetapi lebih berorientasi pada fungsi nada dalam memberi warna rasa gendhing. Berdasarkan komposisi fungsi nada tersebut, Soeroso (1985) berpendapat bahwa ada pathet lain yang diistilahkan pathet $X$ dan pathet

Tabel 1: Teori nada Gong. (Hastanto, 2009)

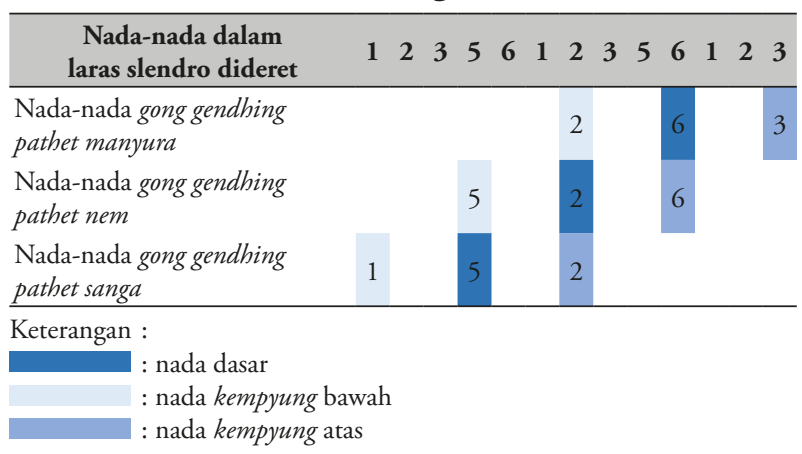

Tabel 2: Visualisasi pembentukan Pathet. (Soeroso, 1985)

\begin{tabular}{cccccc}
\hline U & O & A & E & I & Nama Pathet \\
\hline 3 & 1 & 5 & 2 & 6 & Pathet $X$ \\
1 & 5 & 2 & 6 & 3 & Pathet Sanga \\
5 & 2 & 6 & 3 & 1 & Pathet Nem \\
2 & 6 & 3 & 1 & 5 & Pathet Manyura \\
6 & 3 & 1 & 5 & 2 & Pathet $Y$ \\
\hline Keterangan : & U : hung & O : dhong & A : dhang \\
\multicolumn{5}{c}{ E : dheng } & I : dhing
\end{tabular}


$Y$. Fungsi nada pembentuk pathet tersebut oleh Soeroso (1985) disusun dalam Tabel 2.

Pandangan Hastanto dan Soeroso di atas digunakan untuk menelaah rasa Galong dalam menemukan kesamaan dan perbedaannya dengan pathet Manyura. dari hasil telaah ini dapat diidentifikasi kapasitas Galong sebagai pathet tersendiri atau termasuk pathet Manyura. Fungsi Galong dalam pakeliran dapat ditelaah melalui relasi fungsionalnya dengan gending-gending yang lain dalam pathet Manyura (bandingkan dengan Malinowski, 1944). Fungsi di sini berkenaan pada dinamika dramatic pakeliran yang diidentifikasi dengan mencermati perjalanan tangga dramatic dalam pathet Manyura. Melalui perbanding rasa playon Galong dengan pathet Manyura, dan dinamika dramatic yang terjadi dalam pakeliran akan diketahui fungsi Galong dalam pakeliran.

\section{Posisi Galong dalam Urut-urutan Penyajian Karawitan Pakeliran}

Bangunan satu pertunjukan wayang kulit konvensional pada dasarnya mengikuti model dalam penyajian karawitan, yakni dibagi menjadi tiga pathet dengan urut-urutan pathet Nem, pathet Sanga, dan pathet Manyura. Dari sini tampak bahwa keberadaan karawitan dalam pakelirian bukan sekedar pengiring, tetapi berkaitan dengan makna pertunjukan wayang itu sendiri, dan sekaligus sebagai penentu keberhasilan sebuah pertunjukan wayang. Pembagian pathet ini sangat erat kaitannya dengan pembagian waktu pertunjukan wayang semalam suntuk, dari 21.00 sampai jam 06.00. Pathet Nem terdiri dari tiga jejer yang dimulai sekitar jam 21.00 sampai 24.00. Pathet Sanga terdiri dari dua jejer, dari jam 24.00 sampai jam 03.00. Pathet Manyura juga terdiri dari dua jejer, dari jam 03.00-06.00 (Becker, 1979).

Posisi Galong dalam pakeliran berada di tengah-tengah pathet Manyura. Maksudnya adalah: pakeliran terlebih dahulu masuk dalam pathet Manyura yang ditandai oleh dalang melalui sulukan Lagon Pathet Manyura. Mulai saat ini, gending yang digunakan dalam pakeliran adalah gending pathet Manyura. Menjelang adegan perang ageng, pada umumnya dalang melantunkan sulukan
Galong sebagai tanda bahwa iringan selanjutnya adalah gendhing atau Playon Galong. Berakhirnya adegan perang ageng, dalang kembali melantunkan sulukan pathet Manyura, dan diikuti karawitan pathet Manyura. Perubahan pathet tersebut sebagai tanda bahwa pakeliran masuk dalam adegan perang brubuh. Isyarat kembalinya ke pathet Manyura kadang-kadang digunakan kata "sampak" dalam dialog tokohnya. Garis besar urut-urutan penyajian gending dalam pakeliran konvensional tradisi pedalangan Ngayogyakarta, kurang lebihnya digambarkan dalam Tabel 3 .

Berdasarkan Tabel 3 tersebut tampak bahwa posisi Galong berada di tengah-tengah pathet

Tabel 3: Urutan Penyajian Karawitan Pakeliran dalam pertunjukan wayang Tradisi Ngayogyakarta. (Kayam, 2001)

\begin{tabular}{|c|c|}
\hline Adegan & Karawitan \\
\hline 1 Adegan sitinggil jejer I & $\begin{array}{l}\text { Ayak-ayak, gendhing karawitan, ladrang } \\
\text { karawitan. Catatan: ketiga gendhing ini } \\
\text { berlaras slendro pathet Nem, serta dimainkan } \\
\text { secara berurutan (midley) }\end{array}$ \\
\hline 2 Kedhatonan & $\begin{array}{l}\text { Gendhing ayak-ayak laras slendro pathet nem } \\
\text { (gendhing ini biasa disebut ayak-ayak kondur } \\
\text { kedhaton) }\end{array}$ \\
\hline 3 Paseban jawi & $\begin{array}{l}\text { Bila dengan gendhing, disertai janturan. } \\
\text { Dapat pula dengan playon laras slendro } \\
\text { pathet Nem atau sering disebut lasem, tanpa } \\
\text { janturan. }\end{array}$ \\
\hline 4 Kapalan & $\begin{array}{l}\text { Lancaran Gagak Setra laras slendro pathet } \\
\text { Nem. }\end{array}$ \\
\hline 5 Perang ampyak & Playon Lasem \\
\hline 6 Adegan I Jejer II & $\begin{array}{l}\text { Gending menyesuaikan kebutuhan, tetapi } \\
\text { masih dalam wilayah pathet Nem. }\end{array}$ \\
\hline 7 Adegan prang simpang & Menggunakan iring playon lasem. \\
\hline 8 Adegan I Jejer III & $\begin{array}{l}\text { Meskipun masih dalam wilayah pathet } \\
\text { Nem, namun untuk memasuki jejer III ini, } \\
\text { suluk yang digunakan sudah menggunakan } \\
\text { pathet Sanga. Pada umumnya menggunakan } \\
\text { gendhing Bondhet, sehingga jejer II ini lazim } \\
\text { disebut jejer Bondhet. }\end{array}$ \\
\hline 9 Adegan prang & Menggunakan playon sanga. \\
\hline 10 Adegan Gara-gara & $\begin{array}{l}\text { Menggunakan pathet Sanga, namun untuk } \\
\text { adegan candaan panakawan, pathet yang } \\
\text { digunakan terserah pada "panakawan". }\end{array}$ \\
\hline 11 Jejer IV & $\begin{array}{l}\text { Semua gendhing yang digunakan berada } \\
\text { dalam pathet Sanga. }\end{array}$ \\
\hline 12 Jejer $\mathrm{V}$ & $\begin{array}{l}\text { Semua gendhing yang digunakan berada } \\
\text { dalam pathet Sanga. }\end{array}$ \\
\hline 13 Jejer VI & $\begin{array}{l}\text { Semua gendhing yang digunakan berada } \\
\text { dalam pathet Manyura, termasuk pula adegan } \\
\text { perang. }\end{array}$ \\
\hline 14 Jejer VII & $\begin{array}{l}\text { Di awal menggunakan gending dan Playon } \\
\text { pathet Manyura. } \\
\text { Menggunakan iringan Playon Galong. } \\
\text { Perubahan ini ditandai dengan sulukan } \\
\text { Galong. } \\
\text { Kembalinya ke pathet Manyura sampai tanceb } \\
\text { kayon. }\end{array}$ \\
\hline
\end{tabular}


Manyura. Artinya, tidak berada awal maupun di akhir pathet Manyura. Perpindahan dari pathet Manyura ke Galong ditandai dengan Suluk Galong atau Ada-ada Galong, tergantung kebutuhan adegan dalam pakeliran.

\section{Persandingan Galong dan Pathet Manyura}

Beberapa pakar karawitan tradisi Ngayogyakarta menyatakan bahwa Galong tidak hanya bentuk playon, tetapi juga bentuk gendhing, ladrang, ketawang, atau yang lainnya. Namun demikian, yang paling menonjol dalam pakeliran adalah sulukan dan playon. Oleh karena itu tulisan ini lebih berfokus pada dua hal tersebut. Meskipun di lapangan kadang digunakan laras pelog, namun analisisnya difokuskan pada laras slendro. Pemilihan ini didasarkan pada kapasitas laras slendro yang dipandang sebagai induk dari laras gamelan (bandingkan dengan Saepudin, 2015).

\section{Sulukan}

Fungsi sulukan dalam pakeliran, salah satunya adalah sebagai penanda perpindahan pathet. Konvensi demikian, dalam pakeliran sudah dipahami oleh para pengrawit, maka ketika dalang membawakan sulukan, pengrawit selalu tanggap dan merespon dalam membawakan gending sesuai dengan pathet maupun laras sulukan. Sulukan juga menentukan bentuk

Tabel 4: Persandingan sulukan Pathet Manyura dan Galong.

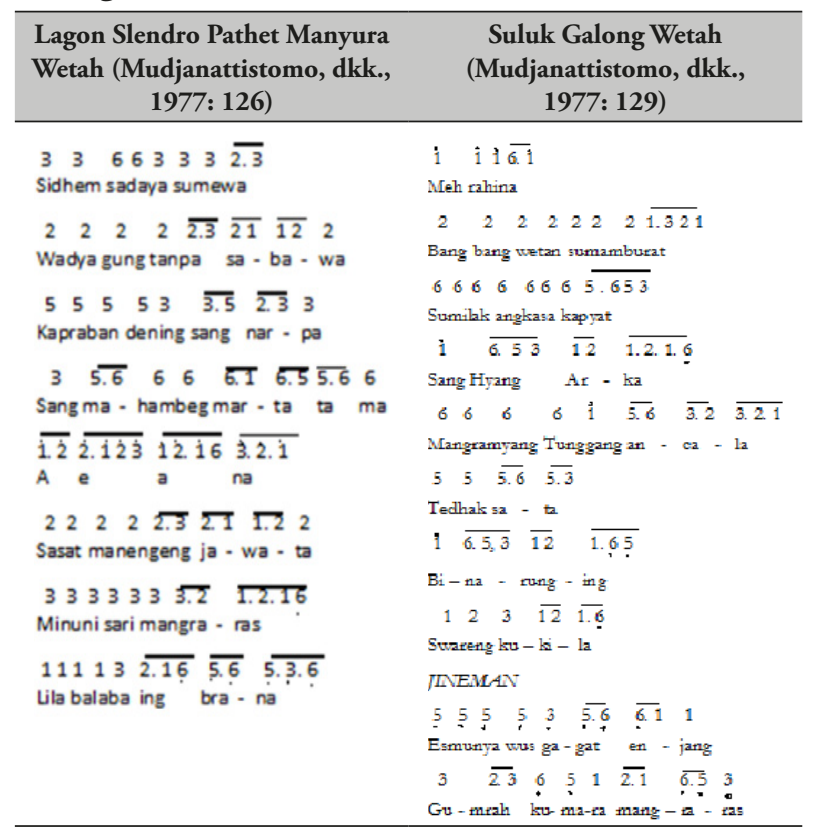

gending. Lagon atau suluk pada umumnya sebagai tanda untuk membawakan gending dalam bentuk gendhing, ladrang, atau ketawang; sedangkan ada-ada sebagai isyarat kepada pengrawit untuk membawakan playon, sampak, atau lancaran.

Kaidah-kaidah tersebut di atas juga berlaku dalam fenomena Galong. Sulukan Galong dalam tradisi pedalangan Ngayogyakarta hanya terdapat dua jenis, yaitu suluk Galong dan adaada Galong. Hal demikian berbeda dengan sulukan dalam pathet Manyura yang terdiri dari lagon, ada-ada, dan sendhon. Sebagai contoh adalah sulukan pada Tabel 4 dan Tabel 5 .

Berdasarkan tabel tersebut tampak bahwa jumlah baris kedua sulukan tersebut adalah sama, yaitu 8 baris, namun dalam suluk Galong terdapat tambahan jineman dua baris. Dari tabel juga tampak adanya perbedaan nada seleh pada tiap-tiap baris.

Istilah yang digunakan untuk nama kedua sulukan tersebut, dalam tradisi pedalangan Ngayogyakarta terdapat perbedaan. Pemilihan nama untuk sulukan dalam pathet Manyura digunakan istilah lagon, sedangkan untuk Galong digunakan istilah suluk. Sedangkan untuk penamaan ada-ada tidak ada perbedaan. Perbedaan demikian tentu terkandung maksud di dalamnya.

Tabel 5: Persandingan dalam sulukan ada-ada.

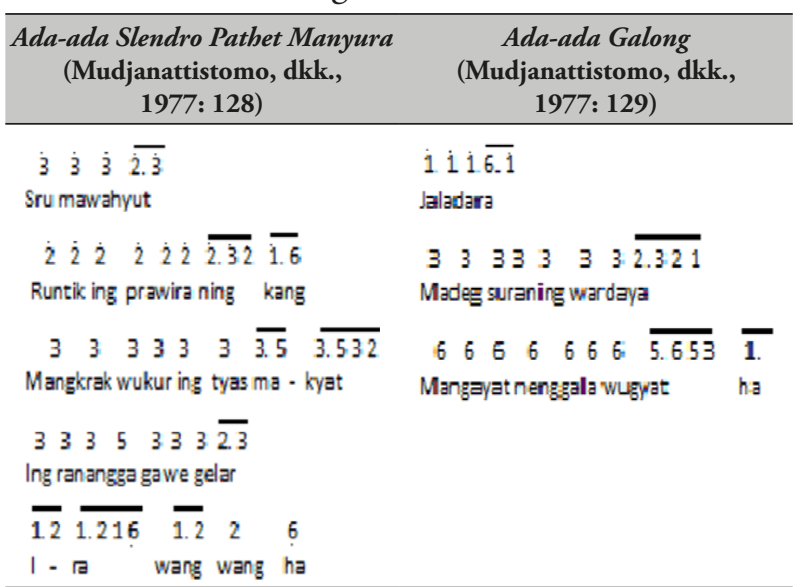

Catatan: penulisan nada di atas menggunakan bilah gender. Nada bertitik bawah menunjukkan pada nada pada wilayah jangkah bawah.

Nada tanpa titik menunjukkan nada pada wilayah jangkah tengah.

Nada titik atas menunjukkan nada pada wilayah jangkah atas. Jangkah adalah susunan nada secara urut dari nada 12356 . 
Istilah lagon, berdasarkan telaah etimologi, berasal dari kata dasar lagu dan akhiran an. Kata lagon dapat diartikan sebagai kategorisasi jenis lagu (tembang); bisa juga diartikan sebagai cara pembawaannya. Dalam tradisi pedalangan Ngayogyakarta, istilah lagon digunakan untuk menyebutkan jenis sulukan yang cara membawakannya dengan irama santai untuk menciptakan suasana agung atau damai atau tenang. Meskipun kurang konsisten, istilah lagon juga digunakan untuk menyebutkan sulukan yang syairnya bersumber dari tembang (periksa Mudjanattistomo, dkk., 1977).

Istilah suluk, baik dalam Bahasa Jawa maupun dalam Bahasa Indonesia lebih dipahami sebagai bentuk syair yang berkenaan dengan mantra atau hal-hal gaib, mistis (Mahmudi, 2005). Dengan demikian sapat diasumsikan bahwa Galong dipandang memiliki makna yang berkaitan dengan hal mistis.

Konsep mistis Galong di atas sangat mungkin berkaitan dengan arti kata galong. Ki Sutejo, seorang dalang senior dari Gedong Kuning yang sekaligus sebagai sesepuh dalang di keraton Ngayogyakarta menjelaskan bahwa arti kata galong adalah gagat isuk, bangun injing, awan (bedhug), lingsir, surup, tengah bengi, mungup, dan aras kembang (Ki Cermo Sutedjo, wawancara 27 Desember 2018). Mayoritas dari makna galong di atas adalah merujuk pada waktu yang bagi orang Jawa dipandang penting dan wingit. Gagat isuk atau menjelang pagi merupakan waktu pergantian dari malam ke siang. Waktu tersebut, bagi orang Jawa dipahami sebagai waktu 'kembali'nya makhluk alam gaib ke tempat masing-masing setelah dalam aktivitasnya semalam. Waktu bedhug atau tengah hari, saat matahari tepat di atas kepala, oleh orang Jawa juga dipahami sebagai waktu yang wingit. Oleh karena itu orang Jawa tradisional selalu menyuruh anak-anaknya untuk pulang dari bermain dan beristirahat di rumah. Demikian juga waktu sore atau surup dipandang sebagai waktu yang gawat. Bukan itu saja, tetapi semua tempat-tempat atau waktu yang menjadi pertemuan selalu dipandang gawat, memiliki daya magis (periksa Wahyudi, 2012). Di sini kita sudah menemu- kan perbedaan istilah yang digunakan dalam sulukan, yaitu untuk pathet Manyura digunakan istilah lagon, sedangkan untuk Galong digunakan istilah suluk. Berdasarkan pengertian istilah tersebut mengindikasikan bahwa suluk Galong lebih memiliki nuansa mistis atau magis daripada lagon Manyura. Sifat magis gendhing tidak hanya berlaku di Jawa. Bahkan di Bali, pada saat upacara ngaben, perjalanan roh dimetaforkan dengan suara gendhing (Arsana, Lono L. Simatupang, Soedarsono, \& Dibia, 2015) (Pandin, 2020).

2. Playon

Kata playon berasal dari kata dasar playu yang mendapat akhiran 'an'. Playu artinya lari. Sebagian masyarakat menyebutkan playon dengan istilah plajaran, yang berasal dari kata dasar plajar dan akhiran 'an'. Plajar adalah bahasa Jawa halus dari playu. Dengan demikian, pengertian kedua istilah tersebut adalah sama. Makna secara asosiatif, lari merupakan proses perpindahan tempat yang lebih cepat dari berjalan, atau diasosiasikan tergesa-gesa, yang dalam bahasa Jawa disebut dengan istilah srepeg atau slepeg. Oleh karena itu dapat dipahami apabila dalam tradisi karawitan Surakarta, untuk playon ini distilahkan srepegan atau slepegan.

Playon, seperti halnya sulukan, playon Galong juga memiliki perbedaan yang signifikan dengan playon Manyura. Perbedaan tersebut dipaparkan dalam balungan playon berikut:

Playon Galong:

Buka: (2)

$$
\begin{aligned}
& \begin{array}{llllllll}
5 & 252 & 525 & (1)
\end{array} \\
& 51525515 \text { (6) } 5115655253 \\
& 515 \text { (6) } \\
& \text { [[ } \begin{array}{llllllllllll}
5 & 1 & 5 & 6 & 5 & 2 & 5 & 3 & 5 & 2 & 5 & (1)
\end{array} \\
& \begin{array}{llllllllllll}
5 & 2 & 5 & 1 & 5 & 3 & 5 & 6 & 5 & 3 & 5 & (2)
\end{array} \\
& 53525515(6) 5156 \\
& \left.\begin{array}{llllllllll}
5 & 2 & 5 & 3 & 5 & 1 & 5 & (6)
\end{array}\right]
\end{aligned}
$$

Suwuk: - - - $6 \quad 5 \quad 5 \quad 12\{3\}$

\section{Playon laras Slendro Pathet Manyura:}

Buka: (2)
$\begin{array}{llllllllll}3 & 2 & 3 & 2 & 3 & 2 & 1 & 3 & 2 & (1)\end{array}$
$\begin{array}{llllllllllllllll}2 & 1 & 3 & 2 & 5 & 6 & 1 & (6) & 5 & 6 & 1 & 6 & 5 & 3 & 2 & 3\end{array}$
$561(6)$ 


$$
\text { [[ } \left.\begin{array}{llllllllllll}
5 & 6 & 1 & 6 & 2 & 3 & 5 & 3 & 2 & 1 & 2 & (1) \\
2 & 1 & 2 & 1 & 3 & 5 & 6 & 5 & 3 & 2 & 1 & (2) \\
3 & 2 & 3 & 2 & 5 & 6 & 1 & (6) & 5 & 5 & 1 & 6 \\
5 & 3 & 2 & 3 & 5 & 6 & 1 & (6) & ]
\end{array}\right]
$$

Suwuk: $\begin{array}{llllll}2 & 1 & 3 & 2 & 1 & \{6\}\end{array}$

Playon Manyura maupun playon Galong memiliki pola kethuk-kenong sama, yaitu setiap balungan adalah satu kenongan, dan kethuk-nya berada di antara tiap-tiap balungan. Dengan demikian berdasarkan konsep padhang-ulihan, playon memiliki 'perjalanan' kalimat yang lebih cepat dibanding bentuk lancaran, ladrang, ketawang, maupun gendhing. Oleh karena itu pola tabuhan tersebut diistilahkan playon. Penamaan ini rupa-rupanya ada korelasinya dengan istilah balungan mlaku dan balungan nibani dalam karawitan.

Perbedaan yang signifikan antara playon Galong dan playon Manyura adalah penggunaan nada padhang. Playon Manyura menggunakan nada padhang yang berbeda-beda dalam keseluruhan nada padhang-ulihan, sedangkan dalam playon Galong menggunakan nada padhang yang sama dalam keseluruhan nada padhang-ulihan, yaitu nada lima. Padahal, nada lima merupakan nada dhing dalam pathet Manyura. Penggunaan nada padhang yang tetap ini lazim disebut pancer.

\section{Relasi Nada dalam Membangun Rasa}

Rasa merupakan efek yang muncul dari nada-nada yang dibunyikan dan direlasikan, hubungannya dengan bentuk padhang-ulihan. Dipahami bahwa sebuah gending merupakan rangkaian nada dalam sebuah bangunan gending yang utuh, dan dari sinilah rasa itu akan terbangun. Artinya bahwa angka dalam karawitan merupakan penanda dari nada yang sekaligus sebagai system symbol (Ayu Fitria, 2018).

Raharja menyatakan bahwa Galong pada dasarnya memiliki wilayah nada tersendiri dalam laras slendro. Namun dengan pertimbangan tertentu, keberadaannya dimasukkan ke dalam wilayah pathet Manyura atau bahkan dianggap sebagai pathet Manyura (Raharja, wawancara 3
Oktober 2018). Sebaliknya Wandiyono dan Suko menyatakan bahwa Galong adalah pathet Manyura yang memiliki garap tersendiri untuk kepentingan pakeliran (Wandiyono dan Suko, wawancara tanggal 1 Januari 2019).

Kapasitas Galong sebagai pathet tersendiri dapat dijelaskan melalui perbandingan analisis rasa yang dimunculkan oleh relasi nada-nada dalam sulukan maupun playon, antara Galong dan pathet Manyura. Analisis ini dimulai dari relasi antar nada terkecil dalam konsep padhang-ulihan. Dipahami bahwa setiap relasi antar nada, apabila dirubah bentuk relasinya atau dirubah nadanya akan menghasilkan rasa yang berbeda.

Padhang-ulihan adalah sesuatu yang imajiner dan menyangkut rasa. Oleh karena masingmasing individu memiliki rasa yang berbeda maka penentuan padhang-ulihan ini sangat relatif dan subjektif (Supanggah, 2009). Namun demikian bukan berarti hal tersebut tidak dapat diidentifikasi. Salah satu cara yang dapat ditempuh adalah menggunakan model kebahasaan. Padhang-ulihan dianalogikan sebagai sebuah kalimat. Padhang dianalogikan sebagai frase dalam sebuah kalimat, sedangkan ulihan adalah anak frase. Frase dan anak frase dalam karawitan berbeda dengan kebahasaan, tetapi memiliki makna tersendiri (Strauss, 1967; Wahyudi, 2012). Rasa musikal dalam menentukan padhang-ulihan pada sajian galong ini digunakan balungan maupun cengkoknya.

1. Sulukan

Sulukan merupakan persoalan penting dalam pakeliran karena salah satu fungsinya adalah sebagai sasmita gending, termasuk pula sasmita perubahan pathet, yang harus dipahami pula oleh pengrawitnya (Harti, 2020). Persandingan sulukan dalam tabel 4 diperoleh tiga hal yang menarik. Pertama, secara keseluruhan, suluk Galong memiliki ambah-ambahan nada yang relatif lebih tinggi dari lagon Manyura. Kedua, dominasi nada pada lagon Manyura adalah nada 3, 2, dan 6; sedangkan pada suluk Galong adalah nada 1 dan 3 yang disertai nuansa nada 5. Ketiga, baik lagon Manyura maupun suluk Galong terdiri dari delapan baris, namun suluk Galong diberi tambahan jineman dua baris. Apabila memperhatikan sulukan yang 
lain dalam pathet Sanga dan Nem, rupa-rupanya penambahan jineman tersebut merupakan ciri khas suluk; seperti suluk Plencung dan suluk Jingking. Artinya bahwa, penambahan jineman pada suluk Galong merupakan pencirijenis suluk dalam tradisi pedalangan Ngayogyakarta.

Baris-baris dalam kedua sulukan di atas apabila diperhatikan kalimat lagu berdasarkan pembawaan dalang dapat ditafsirkan bahwa baris pertama merupakan padhang, baris ke dua merupakan ulihan; baris ketiga sebagai padhang dan baris keempat sebagai ulihan, demikian seterusnya. Artinya, setiap baris gasal merupakan padhang dan ulihan-nya adalah baris genap selanjutnya. Pola padang-ulihan-nya dapat disusun dalam Tabel 6.

1. Padhang-ulihan pertama pada suluk Galong adalah: nada padhang 1 atas dan nada ulihan 1 tengah; sedangkan pada lagon Manyura adalah nada padhang 3 tengah dan nada ulihan 2 tengah.

2. Padhang-ulihan kedua, baik Galong maupun Manyura menggunakan nada padhang 3 tengah dan nada ulihan 6 tengah.

3. Nada ulihan dalam level besar satu sulukan, baik Galong maupun Manyura sama-sama menggunakan nada 6 bawah, namun dalam suluk Galong ditambah jineman yang berakhir atau seleh pada nada 3 bawah.

Analisis rasa padhang-ulihan berdasarkan pembentuk pathet model Soeroso di atas dapat

Tabel 6: Persandingan nada akhir suluk Lagon Manyura dan suluk Galong.

\begin{tabular}{lcccccccccc} 
Sulukan & pdg & ulh & pdg & ulh & pdg & ulh & pdg & ulh & pdg & ulh \\
\hline Lg,M & 3 & 2 & 3 & 6 & 1 & 2 & 6 & 6 & & \\
S1.G & 1 & 1 & 3 & 6 & 1 & 3 & 5 & 6 & 1 & 3 \\
\hline
\end{tabular}

Tabel 7: Pola nada pembentuk pathet pada Lagon Manyura.

\begin{tabular}{|c|c|c|c|c|c|c|c|c|c|c|}
\hline Sulukan & pdg & ulh & pdg & ulh & pdg & ulh & pdg & ulh & pdg & ulh \\
\hline Lg,Myr & 3 & 2 & 3 & 6 & 1 & 2 & 6 & 6 & & \\
\hline $\begin{array}{l}\text { Dhing- } \\
\text { dhong }\end{array}$ & A & $\mathrm{U}$ & A & $\mathrm{O}$ & $\mathrm{U}$ & $\mathrm{U}$ & $\mathrm{O}$ & $\mathrm{O}$ & & \\
\hline Slk.Glg & 1 & 1 & 3 & 6 & 1 & 3 & 5 & 6 & 1 & 3 \\
\hline $\begin{array}{l}\text { Dhing- } \\
\text { dhong }\end{array}$ & $?$ & $?$ & $?$ & ? & $?$ & $?$ & ? & $?$ & ? & $?$ \\
\hline
\end{tabular}

digambarkan pola nada $d$ hing-dhong pada Tabel 7.

Kapasitas pathet suluk Galong dapat diketahui dengan cara menelaah fungsi nada pada tiap-tiap baris sulukan. Agar lebih mudah menganalisisnya, lagu sulukan tersebut ditentukan nada-nada yang berfungsi sebagai nada pokok dan disusun dalam bentuk gatra seperti penulisan gending dalam karawitan. Penentuan nada yang berfungsi sebagai nada balungan dengan cara menganalogikan sulukan sebagai gerongan. Sulukan pada dasarnya dapat dituliskan dalam bentuk gatra. Nada-nada di luar nada balungan dipandang sebagai cengkok lagu. Penentuan gatra berdasarkan rasa padhangulihan. Notasi lagu suluk Galong di atas dapat ditafsirkan bahwa satu baris sulukan sejajar dengan satu gatra dalam gending, yang susunan nada-nada balungan berdasarkan kalimat lagunya adalah sebagai berikut:

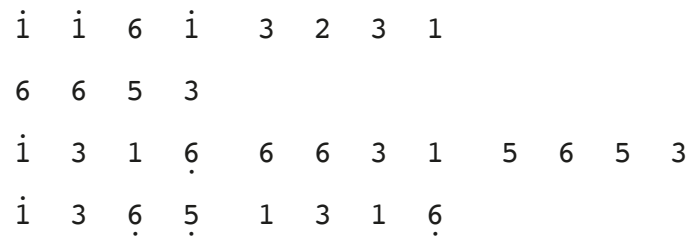

Jineman

$$
\begin{array}{llllllll}
5 & 6 & 5 & 1 & 2 & 5 & 6 & 3
\end{array}
$$

Tiap-tiap baris dipandang sebagai sebuah padhang-ulihan. Artinya bahwa satu padhangulihan tidak selalu harus terdiri dari dua gatra, sebagaimana pola di atas bahwa padhang-ulihan baris pertama terdiri dari dua gatra, baris kedua satu gatra, baris ketiga tiga gatra, baris keempat dan kelima dua gatra.

Padhang-ulihan pada baris pertama terdiri dari dua gatra. Bila gatra pertama sebagai padhang dan gatra kedua sebagai ulihan, maka padhang-ulihannya adalah 1 nada tinggi - 1 nada tengah. Apabila dibagi lagi pada tiap gatra, maka padhang-ulihan gatra pertama adalah 1 - 1 nada atas, dan gatra kedua adalah $2-1$ nada tengah. Pada gatra pertama terdapat nada 6 , yaitu nada yang digunakan sebagai lintasan untuk memberi warna pada garap gantungan 1 . Artinya bahwa nada 6 berfungsi sebagai dheng yang menjadi lintasan untuk seleh 1 . Pada gatra kedua, nada 1 
berfungsi sebagai nada seleh. Untuk menuju nada seleh ini terdapat nada 2 dan 3 yang tersusun 32 31 . Struktur nada ini menunjukkan bahwa nada 3 memiliki tekanan yang relatif kuat, dan nada 2 berfungsi sebagai nada lintasan dari 3 menuju nada seleh 1 . Dengan demikian dapat ditafsirkan bahwa nada 3 di sini berfungsi sebagai kempyung atas (dhang).

Baris ke dua terdiri dari satu gatra 665 3. Nada 3, sebagai nada seleh memiliki tekanan yang paling kuat. Nada 6 meskipun bukan nada seleh tetapi memiliki tekanan yang kuat. Oleh karena itu nada 6 di sini diasumsikan sebagai kempyung atas (dhang). Sedangkan nada 5 merupakan nada lintasan (dhung) dari nada nem ke seleh nada 3. Dengan demikian pada baris ini, kalimat lagu didominasi nada 6, sedangkan nada 5 sebagai lintasan untuk seleh pada nada 3.

Baris ke tiga adalah: $\begin{array}{llllllll}1 & 3 & 1 & 6 & 6 & 6 & 3 & 2\end{array}$ 5653 . Berdasarkan pembawaannya, nada yang memiliki tekanan paling kuat adalah nada 6 karena sebagai nada seleh. Nada 1, meskipun sebagai posisi padhang dalam struktur terkecil, tetapi memiliki tekanan rasa yang kuat. Dengan demikian nada 1 ini berfungsi sebagai kempyung atas. Padhang-ulihan $3-6$ ini merupakan kempyung atas.

Komposisi nada pada gatra ke dua tampak bahwa nada 2 sebagai nada seleh, namun nada 6 sebagai padhang juga memiliki rasa yang kuat. Artinya bahwa nada 6 di sini berfungsi sebagai kempyung atas. Uniknya, gatra ini tidak menunjukkan rasa seleh sebagai sebuah kalimat lagu. Gatra ke tiga terdapat bentuk padhangulihan 6-3; sedangkan nada 5, meskipun sebagai anggkatan suluk, namun posisinya sebagai nada lintasan. Kasus awal sulukan atau angkatan suluk bukan sebagai nada kuat juga dijumpai dalam beberapa sulukan yang lain; seperti angkatan ada-ada kadang-kadang menggunakan nada 3 atau 5 atau nem; tergantung keinginan dalang saat itu. Secara keseluruhan gatra, dalam baris ke tiga ini terdapat komposisi nada 3-6, 6-2, $6-3$. Dengan demikian tampak bahwa baris ini didominasi oleh nada 3 dan 6 dengan 3 sebagai nada seleh.
Baris ke empat adalah 13651216. Gatra pertama menunjukkan bahwa nada 5 adalah nada seleh, namun nada 3 dan nada 6 memiliki rasa yang kuat. Demikian juga nada 1, sebagai angkatan suluk juga memiliki rasa yang kuat. Rasa kalimat lagu sulukan demikian menunjukkan bahwa seleh 5 di sini terkesan lemah, dan kekuatan rasa nada justru pada ketika masuk pada nada 1 sebagai angkatan gatra ke dua 1216 . Gatra kedua, nada 2 memiliki rasa yang kuat dan nada 6 juga memiliki rasa yang kuat dan sekaligus sebagai nada seleh. Dengan demikian, tampak bahwa nada 2 merupakan nada kempyung atas. Nada 1 merupakan nada nada kuat dan sekaligus mendominasi rasa kalimat lagu dalam ke dua ini.

Telaah di atas menunjukkan bahwa dalam sulukan terdapat nada-nada yang berfungsi sebagai kempyung atas, nada kempyung bawah, dan nada seleh (Mustika \& Purwanto, 2021). Keseluruhan kalimat lagu suluk Galong dapat diidentifikasi bahwa nada 1 atas pada akhir lagu sulukan baris pertama berfungsi sebagai kempyung atas. Nada 1 tengah pada akhir lagu baris kedua berfungsi sebagai kempyung bawah. Nada 3 tengah pada akhir lagu baris ketiga merupakan nada seleh. Nada 6 bawah pada akhir lagu sulukan baris keempat merupakan kempyung bawah. Nada 1 tengah pada akhir lagu sulukan baris kelima berfungsi sebagai kempyung bawah. Nada 3 tengah pada akhir lagu suluk baris keenam berfungsi sebagai nada seleh. Nada 5 bawah pada akhir lagu sulukan baris ketuju, meskipun posisinya sebagai akhir lagu namun berdasarkan rasa lagunya, diidentifikasi sebagai kempyung bawah. Nada 6 bawah sebagai nada akhir lagu sulukan baris kedelapan dan sekaligus akhir lagu sulukan seluruhnya, jelas berfungsi sebagai nada seleh. Suluk Galong diberi tambahan jineman yang berakhir pada nada 3 bawah, namun rasa kalimat lagu nada 3 bawah ini sebagai kempyung bawah. Dengan demikian dalam suluk Galong terdapat pola kalimat lagu yang dapat dibuat pembagian wilayah nada kempyung atas dan kempyung bawah berdasarkan kategorisasi nada dhing-dhong yang ditunjukkan pada Tabel 8. 
Wilayah nada dalam Tabel 8 tersebut dapat disusun persandingan padhang-ulihan dalam kapasitasnya sebagai nada dhing-dhong sebagaimana ditunjukkan pada Tabel 9.

Tabel 9 menunjukkan bahwa lagon Manyura dan suluk Galong memiliki ambah-ambahan dan beberapa bentuk padhang-ulihan yang berbeda, namun pada dasarnya memiliki susunan nada pembentuk pathet yang tidak jauh berbeda. Ulihan lagon Manyura didominasi nada 2-6, sedangkan ulihan suluk Galong didominasi nada 1-6 dan 3-6. Fakta tersebut dapat diasumsikan bahwa pada dasarnya konsep nada pembentuk pathet suluk Galong juga menggunakan nada dhong dalam pathet Manyura. Artinya bahwa rasa pathet Manyura pada suluk Galong masih relatif kuat. Varian padhang-ulihan yang lain merupakan upaya untuk memberikan rasa dan karakter yang berbeda dengan lagon Manyura. Pembawaan suluk Galong pun relatif lebih cepat, sehingga rasa yang dihasilkan tampak lebih greget.

\section{Playon}

Tabel 10 menunjukkan bahwa nada ulihan pada setip gatra dalam playon Manyura sama persis dengan nada ulihan playon Galong, baik dari tingkat paling kecil (dua nada) sampai paling besar (keseluruhan). Yang membedakan adalah pola padhang-nya, yaitu playon Manyura menggunakan nada yang berganti-ganti dengan pola mrambat mengikuti ulihan, sedangkan pada playon Galong digunakan nada 5 sebagai

Tabel 8: Persandingan pembagian wilayah nada Galong dengan pathet yang lain.

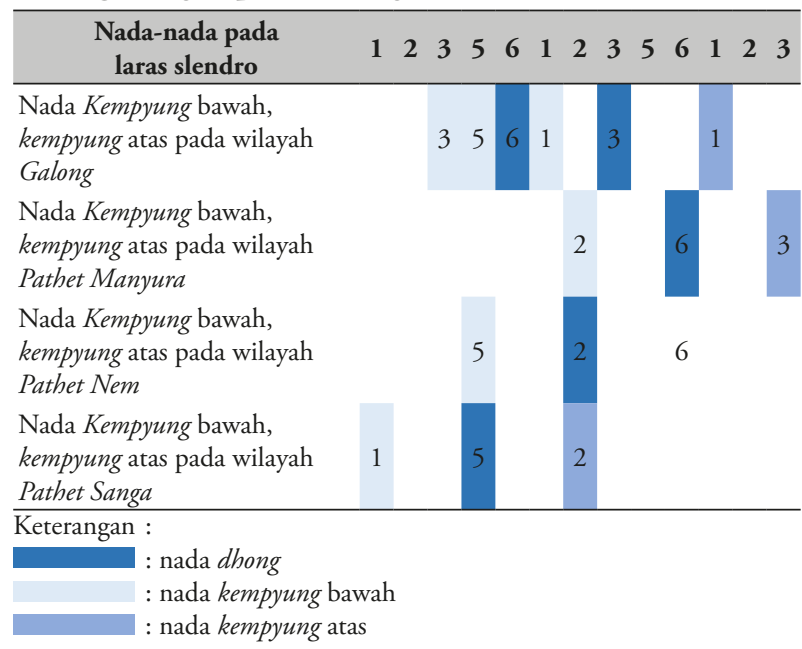

pancer. Hal demikian tampak bahwa meskipun ulihan sama, tetapi padhang yang berbeda telah menghasilkan rasa yang berbeda pula. Artinya bahwa rasa gendhing tidak ditentukan oleh ulihannya saja, tetapi juga padhang-nya. Artinya bahwa rasa gending sangat ditentukan oleh cara nada-nada tersebut direlasikan (bandingkan dengan Wahyudi, 2008).

Pancer 'lima' merupakan hal yang tidak lazim untuk pathet Manyura karena nada lima sebagai dhing dianggap bertekanan ringan sehingga sering menjadi pantangan dalam pathet Manyura (Soeroso, 1986: 85). Namun demikian pantangan tersebut justru digunakan sebagai pancer dalam playon Galong. Artinya bahwa nada lima di sini justru didudukkan sebagai posisi lagu (bandingkan dengan Saepudin, 2015). Nada lima sebagai nada dhing dalam pathet Manyura, oleh karena keberadaannya sebagai posisi lagu maka playon Galong memiliki rasa "baru", yang berbeda dengan rasa playon Manyura. Nuansa baru ini terkesan lebih greget (Widodo, Ganap, \& Soetarno, 2017). Rasa demikian juga untuk kebutuhan greget-sahut dinamika dramatik pakeliran dalam pathet Manyura (Wahyudi, 2014).

Pancer 'lima' dalam Galong galong ini seakan-akan berkesan bahwa galong memiliki Tabel 9: Persandingan pola nada pembentuk pathet pada Lagon Manyura dan suluk Galong.

\begin{tabular}{|c|c|c|c|c|c|c|c|c|c|c|}
\hline Sulukan & pdg & ulh & pdg & ulh & pdg & ulh & pdg & ulh & pdg & ulh \\
\hline Lg,Myr & 3 & 2 & 3 & 6 & 1 & 2 & 6 & 6 & & \\
\hline $\begin{array}{l}\text { Dhing- } \\
\text { dhong }\end{array}$ & A & $\mathrm{U}$ & A & $\mathrm{O}$ & $\mathrm{U}$ & $\mathrm{U}$ & $\mathrm{O}$ & $\mathrm{O}$ & & \\
\hline Slk.Glg & 1 & 1 & 3 & 6 & 1 & 3 & 5 & 6 & 1 & 3 \\
\hline $\begin{array}{l}\text { Dhing- } \\
\text { dhong }\end{array}$ & A & $\mathrm{U}$ & $\mathrm{O}$ & A & A & $\mathrm{O}$ & $\mathrm{U}$ & $\mathrm{O}$ & $?$ & ? \\
\hline
\end{tabular}

Tabel 10: Persandingan balungan Playon Slendro Manyura dan Playon Galong.

\begin{tabular}{lll}
$\begin{array}{c}\text { Baris } \\
\text { ke }\end{array}$ & \multicolumn{1}{c}{ Balungan Playon Manyura } & Balungan Playon Galong \\
\hline Buka & $(2)$ & $(2)$ \\
1 & $--323232132(1)$ & $5252525(1)$ \\
2 & $2132561(6) 56165323$ & $5152515(6) 51655253$ \\
3 & $561(6)$ & $515(6)$ \\
4 & $56162353212(1)$ & $51565253525(1)$ \\
5 & $21213565321(2)$ & $52515356535(2)$ \\
6 & $3232561(6) 5616$ & $5352515(6) 5156$ \\
7 & $5323561(6)$ & $5253515(6)$ \\
Suwuk & $21321(6)$ & $6512(3)$ \\
\hline
\end{tabular}


"dua rasa", yaitu rasa Manyura dan bukan Manyura. Nada 'lima', meskipun merupakan nada dhong pathet Sanga, namun Galong tidak memiliki rasa pathet Sanga. Oleh karena itu, perpaduan nada 'lima' sebagai pancer untuk seleh playon Manyura telah menghadirkan rasa 'baru', yang disebut Galong (bandingkan dengan Suherti \& Sudarsono, 2019).

\section{Kesimpulan}

Keseluruhan uraian di atas menunjukkan bahwa pembagian wilayah nada dhing, kempyung atas, dan kempyung bawah pada Galong memiliki perbedaan dengan pathet yang lain. Meskipun nada ulihan-nya sama dengan pathet Manyura, tetapi rasa baru tersebut dibangun dengan kehadiran nada 'lima'. Penggunaan nada 'lima' sebagai pantangan dalam pathet Manyura, upaya membangun rasa 'baru' dalam garap karawitan pakeliran, yang membedakan Galong dengan rasa pathet Manyura. Hal tersebut sekaligus untuk memberikan penekanan pada nada ulihan agar menghasilkan karakter dan rasa yang lebih sereng dibanding playon Manyura. Artinya bahwa Galong dapat dikatakan sebagai pathet tersendiri.

Rasa Galong tersebut apabila dikaitkan dengan kapasitas sampak Manyura sebagai klimaks dalam pertunjukan wayang, dan posisi Galong berada di antara playon dan sampak Manyura, maka dapat dikatakan bahwa Galong merupakan transisi menuju klimaks. Artinya bahwa pembangunan rasa pathet 'baru' tersebut dilakukan dalam rangka kebutuhan pertunjukan wayang.

Kesimpulan di atas akan berbeda bila pola lagu playon Galong dan playon Manyura ditelaah melalui konsep nada pembentuk pathet. Nada ulihan playon Galong yang sama dengan playon Manyura menunjukkan bahwa kapasitas nada-nada sebagai dhung - dhong -dhang - dheng - dhing adalah sama. Artinya bahwa playon Galong termasuk pathet Manyura. Penggunaan nada lima (dhing) sebagai padhang dalam playon Galong merupakan cara untuk memberi penekanan pada nada ulihannya sehingga playon Galong memiliki rasa yang lebih greget daripada playon Manyura, yang fungsinya untuk transisi menuju sampak Manyura.
Dua kesimpulan inilah tampaknya yang menjadi dasar perdebatan kapasitas pathet pada Galong yang terjadi dalam dunia karawitan, dan keduanya memiliki alasan yang sama kuatnya. Namun demikian, saya sendiri cenderung berpendapat bahwa Galong merupakan pathet tersendiri, karena makna dan rasa sebuah gending tidak hanya ditentukan oleh sebagian unsur saja, melainkan ditentukan oleh keseluruhan unsur.

Penggunaan nama Galong tentu berkaitan dengan makna istilah galong itu sendiri dan sekaligus waktu yang digunakan untuk menampilkan Galong, yakni menjelang pagi atau gagat rahina.

\section{Kepustakaan}

Arsana, I. N. C., Lono L. Simatupang, G. R., Soedarsono, R. M., \& Dibia, I. W. (2015). Kosmologis Tetabuhan dalam Upacara Ngaben. Resital: Jurnal Seni Pertunjukan, 15(2), 107-125. https://doi.org/10.24821/ resital.v15i2.846

Ayu Fitria, I. (2018). Balungan Ladrang Slamet Laras Slendro Pathet Manyura Ditinjau dari Konsep Mancapat. Resital: Jurnal Seni Pertunjukan, 19(3), 131-145. https://doi. org/10.24821/resital.v19i3.3512

Harti, S. (2020). Sasmita gendhing : 12(2), 199205.

Hastanto, Sri. 2009. Konsep Pathet dalam Karawitan Jawa. Surakarta: ISI Press Surakarta, Hastuti, K., \& Mustafa, K. (2016). A method for automatic gamelan music composition. International Journal of Advances in Intelligent Informatics, 2(1), 26-37. https://doi. org/10.26555/ijain.v2i1.57

Kayam. Umar. 2001. Kelir Tanpa Batas. Yogyakarta: Gama Media.

Martopangrawit. 1975. "Pengetahuan Karawitan 1" Diklat untuk kalangan sendiri (Surakarta: ASKI Surakarta.

Mudjanattistomo, dkk. 1977. Pedalangan Ngayogyakarta. Yogyakarta: Yayasan Habirandha Ngayogyakarta.

Muschalla, B., \& Weimann, M. (2021). International Journal of Educational Research Open Capacities rather than psychopathology 
or information explain how high school finishers are attracted by academic studies. International Journal of Educational Research Open, 2-2(December 2020), 100030. https:// doi.org/10.1016/j.ijedro.2020.100030

Mustika, E. M., \& Purwanto, D. (2021). Garap Gembyang Dan Kempyung Dalam Gendèran Gendhing Gaya Surakarta. Keteg: Jurnal Pengetahuan, Pemikiran Dan Kajian Tentang Bunyi, 20(2), 106-119. https://doi. org/10.33153/keteg.v20i2.3545

Nugroho, A. S. (2019). Iringan Karawitan Pergelaran Wayang Golek Menak Yogyakarta Versi Ki Sukarno. 3(2), 140-152.

Pandin, M. G. R. (2020). Moral-ethics-belief values towards indonesian puppet (Wayang kulit) performance arts. Utopia y Praxis Latinoamericana, 25(Extra1), 515-521. https://doi.org/10.5281/zenodo.3784909

Saepudin, A. (2015). Laras, Surupan,. Resital : Jurnal Seni Pertunjukan ISI Yogyakarta, 16(1), 52-64. Retrieved from http://journal.isi.ac.id/ index.php/resital/article/download/1274/216

Sergeant, D. C., \& Himonides, E. (2016). Gender and music composition: A study of music, and the gendering of meanings. Frontiers in Psychology, 7(MAR), 1-15. https://doi. org/10.3389/fpsyg.2016.00411

Setiawan, S. (2019). Unsur Kompetisi Musikal Dalam Sajian Gending Gamelan Sekaten. Keteg: Jurnal Pengetahuan, Pemikiran Dan Kajian Tentang Bunyi, 18(1), 14-24. https:// doi.org/10.33153/keteg.v18i1.2393

Simon, J. (2020). Institutions, Ideologies, and Comparative Political Theory. Perspectives on Politics, 18(2), 423-438. https://doi. org/10.1017/S1537592719001178

Soeroso. 1985/1986. "Pengetahuan Karawitan: Laporan Pelaksanaan penulisan Buku/Diktat Perkuliahan ISI Yogyakarta” (Yogyakarta: Proyek Peningkatan Pengembangan ISI Yogyakarta.

Sudarko. 2003, Pakeliran Padat: Pembentukan dan Penyebaran (Surakarta: Citra Etnika Surakarta.

Suhastjarja dkk. 1984/1985 "Analisa Bentuk
Karawitan” Laporan Pelaksanaan Penelitian atau Diktat untuk kalangan sendiri pada Akademi Seni Tari Indonesia Yogyakarta. Yogyakarta: ASTI Yogyakarta.

Suherti, O., \& Sudarsono, T. (2019). Estetika Lagu Rincik-rincik dalam Pertunjukan Ronggeng Tayub. Panggung, 29(4). https:// doi.org/10.26742/panggung.v29i4.1050

Wahyudi, A. (2008). Lakon Wahyu Cakraningrat dalam Paradigma Strukturalisme. Resital: Jurnal Seni Pertunjukan, 9(1), 1-9. Retrieved from http://journal.isi.ac.id/index.php/resital/ article/view/396/35

Wahyudi, A. (2012). Lakon Dewa Ruci: Cara Menjadi Jawa; sebuah Analisis Strukturalisme Levi-Strauss dalam Kajian Wayang. Yogyakarta: Bagaskara.

Widodo, Susetyo, B., Walton, S., \& Appleton, W. (2021). Implementation of kupingan method in javanese karawitan music training for foreigners. Harmonia: Journal of Arts Research and Education, 21(1), 105-114. https://doi. org/10.15294/harmonia.v21i1.29993

Widodo, W., Ganap, V., \& Soetarno, S. (2017). Laras concept and its triggers: A case study on garap of jineman Uler Kambang. Harmonia: Journal of Arts Research and Education, 17(1), 75. https://doi.org/10.15294/harmonia.v17 i1.10771

Wikandaru, R., \& Sayuti, S. A. (2019). Ontologi Pathet: Kajian Kritis Terhadap Pathet Sebagai Representasi Norma Pergelaran Wayang. 29(2), 244-274. https://doi.org/10.22146/jf.48784

\section{Informan}

Ki Cermo Sutedjo, Dalang senior dan pengajar di SMK I Kasihan serta Pengageng Abdi Dalem Padalangan Karaton Ngayogyakarta. Tinggal di Yogyakarta.

Raharja, 49 tahun. Dosen di Jurusan Karawitan FSP ISI Yogyakarta.

Suko, Seorang pengrawit pedalangan. Tinggal di Yogyakarta.

Wandiyono, seorang pengrawit pedalangan, tinggal di Yogyakarta. 